number of donor organisations. The meeting brought together a representative group of eleven African publishers. Its purpose was to explore and make firm proposals as to how a consortium of African publishers might collectively market their books in Europe and North America by pooling their resources and knowhow, by producing joint lists and catalogues, and by establishing a small permanent office in the UK to provide centralised order fulfilment, billing and shipping for several publishers. Anyone wishing further information on African publishers involved, range of titles to be stocked, catalogues and promotional material, etc. should address their inquiries to:

Hans Zell

PO Box 56

Oxford

OX1 3EL

Tel. 0865512934.

\title{
FORTHCOMING CONFERENCE
}

The Centro de Estudos de Historia e Cartografia Antiga in Lisbon is organising an international conference for October 1988, entitled 'Euro-African Relations in the Third Quarter of the Nineteenth Century' and limited to sub-Saharan Africa. The period extends from the withering away of the Atlantic slave trade in the 1850 s to the Brussels Conference of 1876, a time during which most Africans still retained political control over their destinies. The focus of the conference is to be on how Africans used this autonomy in their reaction to the new ideas and forms of organisation proposed by Europeans. For more information, write to:

Comissao Organizadora da Reuniao Internacional de Historia de Africa CEHCA

Rua Jau 54

1300 Lisbon.

\section{NEW IBADAN JOURNAL}

Rural Life: a journal of rural development has been launched at the University of Ibadan. Its editors are S. G. Nwoko (Editor-in-Chief), Department of Agriculture Economics, and T. O. Ogunfiditimi, Agriculture Extension Department. It aims to offer 'opportunities to scholars, developers, financiers, investors, entrepreneurs, planners, organisations and policy-makers to share ideas and experience on the economic changes which are taking place in rural areas'. The journal will appear three times a year, beginning in January 1987. For further details write to Dr S. G. Nwoko at the University of Ibadan, Nigeria.

\section{AFRICAN STUDIES INFORMATION RESOURCES DIRECTORY}

African Studies Information Resources Directory, compiled and edited by Jean E. Meeh Gosebrink, has been published by Hans Zell/Saur. It provides a comprehensive reference and research tool for identifying sources of information and documentation on sub-Saharan Africa located in the United States. 